\title{
APPLICATION AND IMPROVEMENT \\ OF HERMETIC COMPRESSOR UNITS OF SHIPBOARD EQUIPMENT OF AIR CONDITIONING AND REFRIGERATION
}

\section{ЗАСТОСУВАННЯ ТА ВДОСКОНАЛЕННЯ ГЕРМЕТИЧНИХ КОМПРЕСОРНИХ АГРЕГАТІВ СУДНОВОГО ОБЛАДНАННЯ КОНДИЦІЮВАННЯ ТА РЕФРИЖЕРАЦІЇ}

\author{
Olena V. Lytosh \\ O. V. Lytosh', \\ olena.lytosh@nuos.edu.ua \\ ORCID: 0000-0002-8109-4680 \\ Ji Ran \\ jr_spike@163.com \\ ORCID: 0000-0002-9352-9725 \\ Ph. D., Associate Professor \\ Ji Ran', \\ Master
}

\author{
${ }^{1}$ Admiral Makarov National University of Shipbuilding, Mykolaiv \\ ${ }^{1}$ Начіональний університет кораблебудування імені адмірала Макарова, м. Миколаїв \\ ${ }^{2}$ Jiangsu University of Science and Technology, Zhenjiang, China \\ ${ }^{2}$ Університет науки та технології Цзянсу, Чженьизян, Китай
}

\begin{abstract}
The issue discussed related to the concept of application and improvement of hermetic compressor units (HCU) of shipboard equipment air conditioning and refrigeration (EACR). The purpose of this study is to analyze the development of HCU in our country and abroad and the prospects for the application and improvement of domestic HCU for shipboard EACR development. The choice and application of HCU (spiral or piston) for shipboard EACR is analyzed. This choice depends on the energy efficiency of the HCU, its reliability, noise level and manufacturing cost. Both piston and spiral HCUs have their most rational areas of application. The following considerations are available in favor of piston HCU for shipboard EACR. Piston HCU are in steady demand due to the proven production technology, high reliability and relatively low cost. They have significant development potential, which will make it possible to optimally use them in the shipboard EACR in the future. In terms of mass, smoothness and compactness, modern piston $\mathrm{HCU}$ are quite competitive with rotary machines, and their characteristics such as ease of manufacture, low cost of maintenance, and maintainability make them attractive to many consumers and, above all, to the shipbuilding industry. Spiral HCUs have certain advantages. However, the complexity of the technology of manufacturing spiral machines, the large initial costs of their production, the stringent requirements for the accuracy of manufacturing the entire structure do not allow to reduce the cost and impede the development of their production by a wide range of enterprises. The development and production of these compressors can only afford the largest world companies. The results of the study showed that with a cooling capacity of up to $16 \mathrm{~kW}$, piston HCU retain their advantage. A study and comparative analysis of the characteristics shows that domestic piston HCUs of the type HGV and HGN correspond to the level of the best samples of domestic and foreign equipment, have significant development potential that will allow them to be successfully used in marine air conditioning and refrigeration equipment in the future.

Key words: hermetic compressor unit; compression refrigeration machine; shipboard air conditioning and refrigeration equipment; piston and spiral HCU; refrigeration coefficient; cooling capacity.
\end{abstract}

Анотація. Обговорюється питання, пов’язане з концепцією застосування і вдосконалення герметичних компресорних агрегатів (ГКА) суднового обладнання кондиціювання і рефрижерації (ОКР). Метою цього дослідження $є$ аналіз розвитку ГКА у нас у країні і за кордоном і перспективи застосування і вдосконалення вітчизняних ГКА для суднового ОКР. Виконано аналіз вибору і застосування ГКА (спіральних або поршневих) для суднового ОКР. Цей вибір залежить від енергоефективності ГКА, його надійності, рівня шуму і вартості виготовлення. I поршневі, і спіральні ГКА мають свої найбільш раціональні галузі застосування. На користь поршневих ГКА для суднового ОКР є такі міркування. Поршневі ГКА користуються стійким попитом завдяки відпрацьованій технології виробництва, високій надійності і відносно невисокій вартості. Вони мають значний потенціал розвитку, який дасть змогу оптимально використовувати їх у судновому ОКР і в майбутньому. Сучасні поршневі ГКА за масою, плавністю ходу і компактністю цілком конкурентоспроможні з роторними машинами, а такі їх характеристики, як простота виготовлення, дешевизна обслуговування, ремонтопригодність, 
роблять їх привабливими для багатьох споживачів і насамперед для суднобудівної галузі. Спіральні ГКА володіють певними перевагами. Однак складності технології виготовлення спіральних машин, великі початкові витрати на їх виробництво, жорсткі вимоги до точності виготовлення всієї конструкції не дають змогу знизити собівартість і перешкоджають освоєнню їх випуску широким колом підприємств. Розробку і виробництво цих компресорів можуть собі дозволити лише найбільші світові фірми. Результати дослідження показали, що у разі холодопродуктивності до 16 кВт поршневі ГКА зберігають свою перевагу. Дослідження та порівняльний аналіз характеристик показує, що вітчизняні поршневі ГКА типу ХГВ і ХГН відповідають рівню кращих зразків вітчизняної та зарубіжної техніки, мають значний потенціал розвитку, який дасть змогу успішно застосовувати їх у судновому обладнанні кондиціювання і рефрижерації і в майбутньому.

Ключові слова: герметичний компресорний агрегат; компресійна холодильна машина; суднове обладнання кондиціювання і рефрижерації; поршневі і спіральні компресори; холодильний коефіцієнт, холодопродуктивність.

\section{FORMULATION OF THE PROBLEM}

Hermetic compressor units (HCU) are an integral part of hermetic steam compressor refrigeration machine (SCRM), which belong to the class of thermotransformers in which the supplied electric energy is converted into cold during the transfer of heat from a low-temperature to a medium-temperature level with the cost of electricity to maintain the corresponding pressure difference. As the working fluid of the SCRM, a low-boiling working fluid - a refrigerant is used, and electricity is consumed by the electric motor of the compressor unit [1].

The rapid development and improvement of hermetic SCRM is not least due to the current trend of transition to environmentally friendly refrigerants (R134A, R404A, R407C, R410A, etc.). However, these refrigerants are expensive and work with polyester oils that are poorly compatible with other brands of oils. Also, their thermodynamic properties are inferior to traditional refrigerants, they are non-azeotropic mixtures, the leakage of which leads to a change in composition and an increase in the nonisothermal process of boiling. Transition to hermetic SCRM partially avoids these shortcomings.

A feature of a hermetic SCRM is that the compressor itself and the electric motor, having a common shaft, bearings, lubrication and cooling systems, form a single compressor unit placed in an airtight casing - an hermetic compressor unit (HCU), which largely determines the reliability of the SCRM and the technical economic indicators of her work [2].

The process of improving the HCU, the creation of new types is going around the world. There are a number of original directions that can find application in the HCU. We have considered only those types of HCU that really compete with piston $\mathrm{HCU}$ and are of interest for domestic engineering, including shipbuilding. These are, first of all, rotary machines: rotary, screw and spiral HCU.

\section{ANALYSIS OF RECENT RESEARCH} AND PUBLICATIONS

Rotary compressors began to be used in the 1930s in home refrigerators. However, they really made themselves known after introducing them in a hermetic version into air conditioning systems. Currently, the simplest designs have gained distribution: with a rolling rotor and one blade, with a rotating rotor and two or four plates. The main field of application is air conditioners, since it is difficult to obtain high volumetric and energy indicators at pressure drops of more than $0.3 \ldots 0.4 \mathrm{MPa}$. Rotary machines (in comparison with piston HCU) are characterized by greater compactness, fewer structural elements, and better balance. As disadvantages, it is necessary to point out the manufacturing complexity, higher friction losses, faster wear of the plates, increased noise level and oil entrainment, less maintainability. Rotary HCU in the field of conditioning up to $5 \mathrm{~kW}$ compete with piston ones. However, they were widely used only in stationary objects, which do not have high requirements for reliability, shock and vibration stability. In addition, on ships, climate systems up to $5 \mathrm{~kW}$ have very limited use [2].

Screw compressor units began to be widely used in refrigeration in the 1970 s. This process continues at the present time. The most famous screw compressor manufacturers are Carrier, York, Sabroe, Trane, Bitzer and others. Hermetic screw compressor units deserve special interest. Screw HCU have the following advantages: absence of progressively moving parts, flow continuity, compact design, smooth regulation of performance. As disadvantages, it is necessary to point out the complexity of manufacturing (expensive special equipment is required), the initial costs for the production of screw compressors, strict requirements for the accuracy of manufacturing of the entire structure, are very high, etc. [3]. There are a number of studies showing a reduction in energy consumption when using screw compressors for refrigeration systems [4].

The widely advertised special type of rotary machines - spiral HCU is arouses great interest. Spiral compressor unit refers to volumetric compressors. The patent for a "rotary machine", which was based on the principle of the future scroll compressor, was obtained in 1905. However, until the mid of 70s of the last century, this type of compressor was not developed or manufactured due to technological problems that could be solved only with the advent of numerically controlled machines. Japan and the United States in the early 90 s of the last century were the first to master new technologies and put into production spiral HCU. Now the number of industrial 


\section{ЕНЕРГЕТИЧНЕ МАШИНОБУДУВАННЯ № 1-2020}

designs of spiral HCU produced by firms in the USA, Japan, Germany, France, etc., is estimated at millions of units per year. Only Copeland, a member of Emepson Electric Co (USA), has produced more than 40 million units since the 1990s [5].

Compared to piston $\mathrm{HCU}$, spiral compressor units are distinguished by fewer structural elements, a better degree of reliability, greater compactness, and high energy performance. First of all, it is necessary to point out the complexity of manufacturing: expensive special equipment is required, in particular high-speed milling machines and centres for processing spiral surfaces, a three-coordinate measuring machine, etc. Therefore, the initial costs of producing spiral HCU are very high. In particular, Copeland's investments in research and improvement of spiral technology exceeded $\$ 15$ million, and $\$ 250$ million in preparation for the production and launch of compressors in series. In addition, strict requirements are placed on the accuracy of manufacturing of the entire structure (tolerances for manufacture is about 1 ... 2 microns) [6].

Piston hermetic compressor units are still the most massive (more than 70 million units per year), the cheapest, most technologically advanced in manufacture and universal in application. Well-proven for many decades, they have now reached a certain level of excellence due to modern manufacturing technology. Their further development follows the path of optimizing design and operational parameters, improving technology, creating new models $[6 ; 7]$.

Some manufacturers of spiral HCU, not considering the specific working conditions, are trying to implement them in all SCRM (including shipboard ones) due to the fact that spiral indicators have better indicators than piston ones [8].

From the analysis of studies and publications it follows that there was a problem of choice and prospects for the use of various types of HCU, in particular, for SCRM of shipboard equipment air conditioning and refrigeration (EACR).

\section{PURPOSE OF THE STUDY}

Analysis of the development of hermetic compressor units (HCU) in our country and abroad and the prospects for the application and improvement of domestic HCU for shipboard equipment air conditioning and refrigeration (EACR).

\section{MAIN MATERIAL}

The world leading companies, along with the development of spiral technologies, continue to successfully improve piston compressors, achieving high rates not inferior to rotary machines [6].

So, Bitzer company created a new series of Octagon piston compressor units, in which the following parameters were improved: smoothness and noise characteristics, efficiency, performance control, overall dimensions and weight, cost. This was achieved thanks to the new cylinder head with pulsation damper and performance regulation by changing the speed of the crankshaft by adjusting the frequency of the supply current in the range of $20 \ldots 70 \mathrm{~Hz}$ with an integrated frequency converter. This allowed to saving up to $40 \%$ of electricity in the process of work. When comparing piston HCU Octagon with spiral ones, it was revealed that the former have the best characteristics in the field of low temperatures, are more reliable, are better repaired.

Copeland, which successfully implements spiral technologies, not only does not refuse to produce reciprocating compressor units, but also continues to successfully improve them. Copeland produces Discus semi-hermetic piston compressor units, which have design features that give certain advantages to this type of machine.

The presence of a vent valve installed between the suction cavity and the crankcase of the compressor avoids foaming of oil, water hammer and "oil starvation" and increases the reliability of the compressor during start-up. The new Discus Delta valve plate design with rigidly mounted annular plate suction and disk discharge valves minimizes relative "dead" volume (up to $1 \%$ ) and significantly improves piston compressor efficiency. The quality parameters of the built-in electric motors are also improved. These design features made it possible to obtain boiling points up to $-45^{\circ} \mathrm{C}$ using single-stage compressors.

The Bock research centre (Germany) designed semihermetic piston compressors of the HA type with cooling of the electric motor and the compressor itself by the flow of external air from the aerodynamic casing from an independent fan located at the end of the compressor. The electric motor of the type HA compressor is located outside the vaporous refrigerant flow, which leads to a significant increase in overall efficiency. As a result of the fact that the flow of refrigerant enters directly into the suction cavity and the compressor cylinder, without heating when passing through an electric motor, the final compression temperature does not exceed $140^{\circ} \mathrm{C}$. This makes it possible to operate the compressor both in the medium and low temperature range at a boiling point up to $-45^{\circ} \mathrm{C}$.

Danfoss Maneurop has developed the VTZ Compressor Drive ${ }^{T M}$ piston HCU series, highly efficient and economical in operation, with an adjustable shaft speed of 30 to $90 \mathrm{~s}^{-1}$ (the frequency of the supply current varies from 30 to $90 \mathrm{~Hz}$ ), which depends on the required performance. The power consumption of VTZ compressors is lower than a fixed speed rotary HCU. Total energy savings of up to $40 \%$.

In connection with the foregoing, the question arises about the prospects for the use of piston HCU in the future, in particular, for EACR in the context of a constant increase in energy efficiency, increased reliability, and reduced production costs. 
This question is ambiguous and the choice of HCU depends on various factors that must be taken into account by the developer at the design stage of the equipment and, first of all, such indicators of HCU as: purpose (cooling capacity, scope); reliability (reliability, durability, maintainability); economic (energy efficiency, production costs); ergonomic (noise, vibration, compliance with safety requirements). Only taking into account all factors, the developer can determine the type of $\mathrm{HCU}$ that is most suitable for a specific task [2].

The company Bristol Compressors Engineering, having many years of experience in the development and production of piston and spiral $\mathrm{HCU}$, has conducted comparative tests of the improved Benchmark piston $\mathrm{HCU}$ of its own production and the spiral company Copeland [9; 10].

When comparing the energy efficiency of reciprocating and scroll compressors, it was found that at standard boiling temperatures $\mathrm{t}_{0}=10^{\circ} \mathrm{C}$ and condensation temperatures $\mathrm{t}_{\mathrm{c}}=38^{\circ} \mathrm{C}$ in $\mathrm{SCRM}$ with cooling capacity up to $16 \mathrm{~kW}$, Copeland HCU were inferior in energy efficiency to Benchmark piston HCU.

The feed coefficient of the piston HCU depends on the operating mode of the HCU (condensation temperatures $t_{c}$ and boiling point $\mathrm{t}_{0}$ ). At condensation temperatures of not more than $45^{\circ} \mathrm{C}$, a piston $\mathrm{HCU}$ provides a greater mass flow rate than a spiral one with the same nominal capacity.

Without taking into account the degree of reliability of the HCU during operation as part of the SCRM, it is not possible to determine the advantages of a piston or spiral $\mathrm{HCU}$, since both piston and scroll compressors have their own advantages.

First of all, this concerns the area of operating modes of the HCU (compression ratio or ratio of discharge and suction pressures $\left.\mathrm{P}_{\text {dis }} / \mathrm{P}_{\mathrm{su}}\right)$. Piston $\mathrm{HCU}$ have valves that allow a compression ratio of about 14 to work without damage. In spiral HCU, the compression ratio of 7 is the limit of their operating modes. Spiral HCU designed for a specific compression ratio are much more sensitive to its deviation from optimal conditions. A quick change in the degree of compression usually occurs in refrigeration units in the defrost mode, where a pressure jump causes instability in the operation of the HCU circuit, the appearance of additional load on the mechanisms, and also causes an unpleasant sound when starting the freezing cycle.

Spiral HCU are more susceptible to mechanical damage in the absence of suction, since the coils are lubricated with oil in the refrigerant stream. Piston HCU, where the lubrication system continues to operate regardless of the flow of refrigerant, can function without mechanical damage for a long time.

As for production costs, the following should be noted. In spiral HCU, the surface area to be treated is approximately three times larger. Their production requires, in comparison with relatively simple operations for the production of piston $\mathrm{HCU}$, high-precision operations, the slightest deviations in the performance of which leads to a deterioration in performance. This greatly affects the cost.

An important factor influencing the choice of $\mathrm{HCU}$ is the compressor noise and vibration level. HCU with good energy performance and high reliability, but increased noise or vibration, will not be competitive [2].

Spiral HCU usually have a lower noise level compared to piston ones. However, Bristol Compressors Engineering, by improving the gas distribution system and housing design, as well as using special silencers on the suction and discharge sides, allowed the Benchmark piston HCU to be compared with the best spiral HCU in noise level.

Such an improvement in the design of piston HCU allowed us to achieve a lower noise level than the best spiral HCU. So, tests of the unit with a cooling capacity of $10.5 \mathrm{~kW}$ showed that the noise level for the Copeland spiral HCU was $77.8 \mathrm{~dB}$, and for the Benchmark piston compressor with improvements - 76.2 dB [9; 10].

The SCRM noise level is determined not only by the noise level of the HCU itself. It also depends on the noise of the condenser fan operating (during air cooling), as well as on the pulsations of the gas flow and vibration of mechanisms, pipelines, etc. Spiral HCU, the mechanism of which is rigidly fixed in the casing, transmit significantly more vibrational energy to the SCRM system. In reciprocating $\mathrm{HCU}$, the compressor is fixed in the casing using spring vibration isolators, which reduces the amount of energy transmitted to the system.

Thus, when answering the question of which compressor is most suitable, it can be argued that this choice depends on the energy efficiency of the HCU, its reliability, noise level and manufacturing cost. Both piston and spiral HCU have their most rational areas of application. The following considerations are in favour of piston HCU for marine EACR and development.

A significant part of the hermetic SCRM of shipboard EACR is structurally made in the form of a single unit (module) with a capacity of $15 \mathrm{~kW}$, is used in many modifications of EACR and can be used in installations of higher productivity by means of a set of modules [7].

Most shipboard SCRM are equipped with watercooled condensers, as a result of which, even at the highest temperature of sea water $\left(\mathrm{t}_{\mathrm{s} . \mathrm{w}}=32^{\circ} \mathrm{C}\right)$, the condensation temperature $t_{c}$ does not exceed $42 \ldots 44^{\circ} \mathrm{C}$. At such $t_{c}$, the piston $\mathrm{HCU}$ provides a larger mass flow rate than a spiral one with the same nominal capacity.

Piston HCU have higher values of mechanical efficiency, since their friction losses are $25 \%$ less than spiral ones. Piston machines are more energy efficient and cheaper in systems with a cooling capacity of up to $16 \mathrm{~kW}$.

Piston HCU lubricants are lubricated independently by a centrifugal pump, while spiral ones are lubricated by the oil contained in the refrigerant stream.

Since the sealing of spiral HCU is created by an oil film, high axial and radial matching of the spiral elements is required, and it is also necessary to use perfectly pure 


\section{ЕНЕРГЕТИЧНЕ МАШИНОБУДУВАННЯ №1-2020}

oils with stable properties over a wide temperature range. This leads to low maintainability, and also creates serious difficulties during installation due to the required high purity of the internal surfaces and the inadmissibility of mixing with other types of oils.

Radial compliant structures used by some manufacturers, as well as floating axial seals, are subject to increased wear and significantly reduce reliability.

The use of scroll compressors with high compression ratios presents serious difficulties due to the large area of axial seals. Even with small wear, overflows from cavities high in the low-pressure cavity sharply increase, which significantly reduces volumetric and energy coefficients.

In view of the above, and also taking into account the fact that the productivity of the SCRM module for shipboard EACR is $15 \mathrm{~kW}$, when answering the question: which compressor (piston or spiral) is most suitable for shipboard EACR, it can be argued that in the field of small and medium performance (up to $16 \mathrm{~kW}$ ) piston HCU retain their position.

The first domestic piston HCU of the KHG type for marine air conditioners were developed by "Teplotehnik" (in the future CSR and DI "Typhoon") in 1965. The series consisted of four models with cooling capacity from 2.56 to $16.3 \mathrm{~kW}$ (at boiling points $\mathrm{t}_{0}=5^{\circ} \mathrm{C}$, condensation $\mathrm{t}_{\mathrm{c}}=40^{\circ} \mathrm{C}$, suction $\mathrm{t}_{\mathrm{su}}=20^{\circ} \mathrm{C}$ and supercooling $\mathrm{t}_{\mathrm{u}}=35^{\circ} \mathrm{C}$ ). Synchronous shaft speed $25 \mathrm{~s}^{-1}$, refrigerant $-\mathrm{R} 22$. In terms of volumetric, energy and mass indicators, HCU were not inferior to similar domestic and foreign samples with the same speed.

Over 25 years of experience in the production and operation of these KHG revealed design flaws (the likelihood of a water hammer, the use of difficult and unreliable forked connecting rods, intense wear of the upper main bearing, etc.).

The indicated design flaws were taken into account when creating the CSR and DI "Typhoon" in 1974 of a high-speed $\mathrm{HCU}$ of the KHGV-14 type for marine autonomous air conditioners of amphibious ships powered by a $400 \mathrm{~Hz}$ network. A synchronous rotation speed of 66.7 $\mathrm{s}^{-1}$ was adopted for it, since at a lower frequency $\left(50 \mathrm{~s}^{-1}\right)$ the characteristics of the built-in electric motor deteriorated, which led to a decrease in the performance and an increase in the temperature level of the HCU in general [11].

KHGV-14 (high-temperature hermetic refrigerant compressor, 14 - rated cooling capacity $(\mathrm{kcal} / \mathrm{h})$, reduced by 1000 times) is a two-cylinder unit with an angular (at an angle of $90^{\circ}$ ) cylinder arrangement, which made it possible to make connecting rods with an integral lower head and eccentric shaft with one connecting rod journal. Such compressors are easier to master in small-scale production. The valves are ring, the rated power consumption is 5.52 $\mathrm{kW}, \mathrm{R} 22$ refrigerant is used as a working medium. As a result of the use of internal vibration isolation (conical spring vibration isolators), the vibration level decreased by $8 \ldots 10$ $\mathrm{dB}$ compared to a $\mathrm{KHG}$ compressor having a rigid mount.
The experience of domestic and foreign compressor engineering convincingly shows that the development and improvement of HCU is on the path to increasing the speed, optimizing design and operational parameters. Previously developed domestic hermetic RHC compressor units with a synchronous speed of $25 \mathrm{~s}^{-1}$ for shipboard design work did not fully meet modern requirements (in terms of speed, reliability, noise, vibration, etc.) for shipboard EACR.

HCU with a rotation speed of $50 \mathrm{~s}^{-1}$ is $10 \ldots .20 \%$ cheaper than machines with $25 \mathrm{~s}^{-1}$ [2]. It was established that four-cylinder gas turbines (KHG - 9, KHG - 14) are the most labour-intensive in manufacturing, and a noticeable economic effect should be expected from replacing four-cylinder HCU with a rotational speed of $25 \mathrm{~s}^{-1}$ with two-cylinder ones with $50 \mathrm{~s}^{-1}$. This was one of the reasons for the creation of a new series of hermetic reciprocating compressor units of the HGV type (hightemperature hermetic refrigerant) with a synchronous speed of $50 \mathrm{~s}^{-1}$. HCU of a new series are distinguished by the breadth of coverage of the required cooling capacity (from 3 to $33 \mathrm{~kW}$ ) and can completely replace the obsolete HCU of the KHG type [12].

Compressors of type HGV (Fig. 1) are an aggregate with a built-in electric motor enclosed in a steel casing, with internal vibration isolation and a remote silencerreceiver on the discharge line. During their development and improvement, they made the most of the experience of creating a HCU with a synchronous speed of $66.7 \mathrm{~s}^{-1}$.

To prevent water hydraulic and reduce oil entrainment in the HGV compressors (see Fig. 1), a device is provided consisting of a centrifugal lionfish mounted on the upper end of the shaft in the suction path. To ensure intensive cooling of the electric motor and reduce noise at the suction, a special silencer hood is installed above the electric motor.

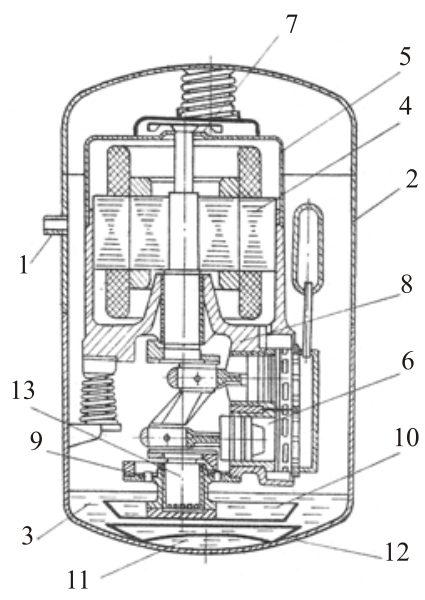

Fig. 1. Hermetic compressor unit type HGV (longitudinal section):

1 - suction pipe; 2 - a tight casing; 3 - oil; 4 - electric motor; 5 - a cap of the electric motor; 6 - cylinder; 7 - hole in the cap of the electric motor; 8 - block crankcase; 9 - pipe; 10 - disk; 11 - stagnant zone; 12 - a guard; 13 - shaft 
Structurally, the HCU series is made on two basic cylinder diameters: 36 and $50 \mathrm{~mm}$. In this case, the optimal ratio, cylinder diameter and piston stroke were selected. Three models are unified among themselves HGV-2.2, HGV-4.5, HGV-9.0 and two models - HGV14.0, HGV-28.0. Unification according to the connecting rod-piston groups, valve devices, parts of the crankcase, the casing exceeds $80 \%$.

The creation and development of the production of new high-speed (with a synchronous speed of 50 and $66.7 \mathrm{~s}^{-1}$ ) piston $\mathrm{HCU}$ for marine air conditioners required a significant amount of theoretical and experimental research to refine and improve these machines, which made it possible to solve the problems of increasing energy efficiency, reliability and optimization of the latter. Their refrigeration coefficient is increased by $10 \ldots 12 \%$, and the resource is increased from 25 to 40 thousand hours.

In Fig. 2 shows the characteristics of the advanced compressor units HGV4.5 and HGV-14 in the form of the dependence of the cooling capacity $\mathrm{Q}_{0}$ and the electric refrigeration coefficient (conversion coefficient) $\varepsilon_{\mathrm{e}}$ on temperatures.
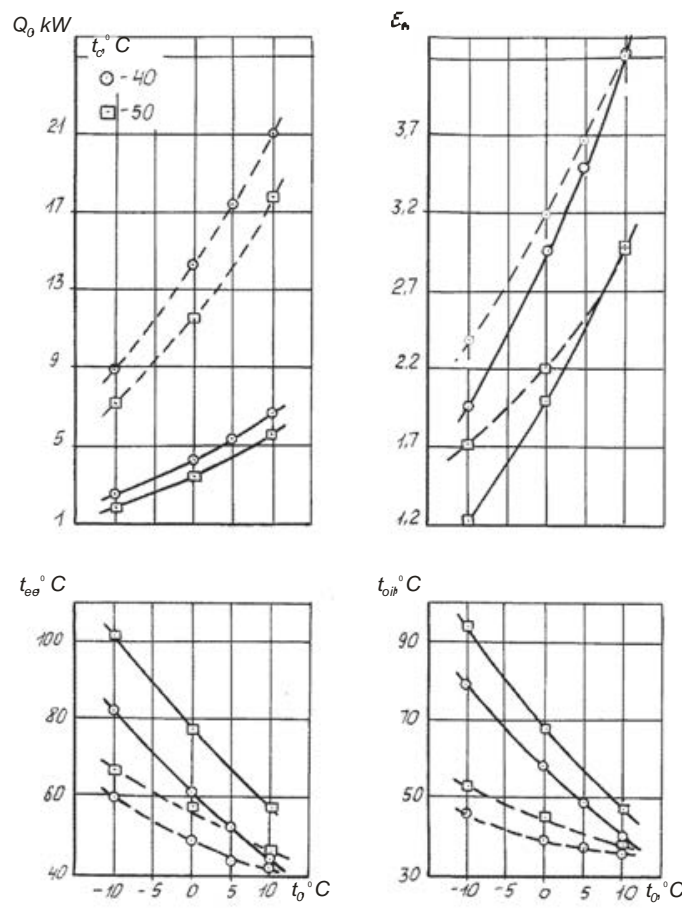

Fig. 2. Characteristics of compressor units:

$$
\text { HGV-4,5; - - - - HGV-14,0; }
$$

$\mathrm{t}_{\mathrm{c}}, \mathrm{t}_{0}, \mathrm{t}_{\text {oil }}, t_{\mathrm{ee}}-$ condensation, boiling, oil, electrical engine windings;

$$
\circ-\mathrm{t}_{\mathrm{c}}=40^{\circ} \mathrm{C} ; \square-\mathrm{t}_{\mathrm{c}}=50^{\circ} \mathrm{C}
$$

In Fig. 3 shows the dependences of the conversion coefficient $\varepsilon_{\mathrm{e}}$, specific metal consumption $g$, and specific overall volume $\mathrm{V}$ on the nominal refrigerating capacity $Q_{n}$ for domestic refrigerated caskets ("Odeskholodmash"
Production Association, PC CSR and DI "Typhoon") and leading foreign companies (USA "Tecumseh", "Mitsubishi" Japan and other). The characteristics of the HCU (except for PG5) were obtained as a result of their tests with the participation of the author at the stands of the CSR and DI "Typhoon", and PG5 was taken from the reference data [8].

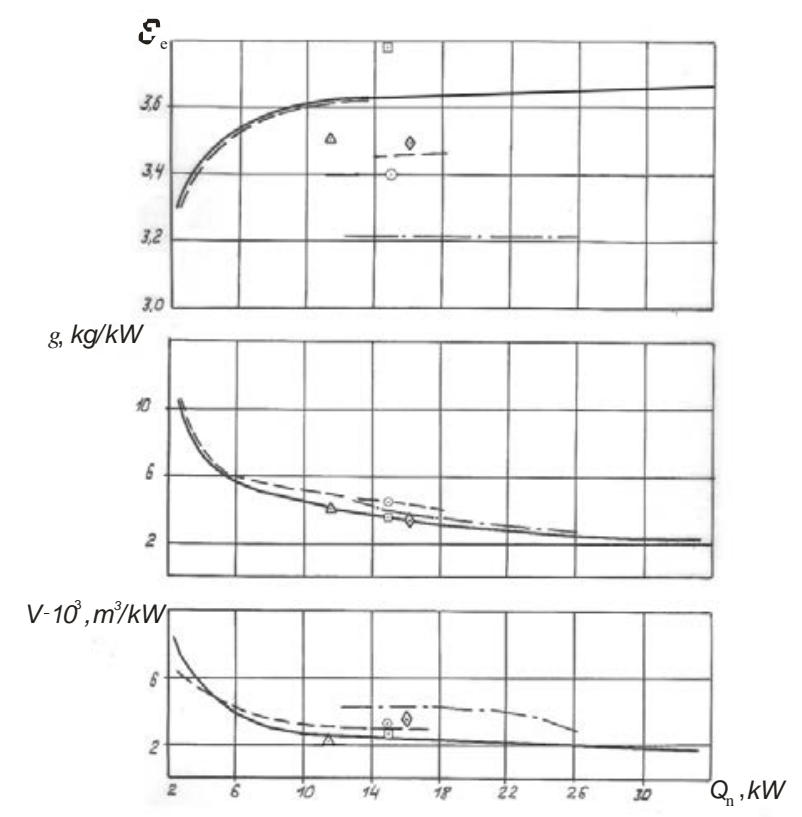

Fig. 3. Dependences of the conversion coefficient $\varepsilon$, specific metal consumption $g$ and specific overall volume $V$ on the nominal refrigerating capacity $Q_{n}$ for domestic and foreign commercial refrigerated equipment:

- HGV; - - - - KHG; - - - - PG; $\triangle-C L 41 Z \mathrm{AA} 17$

"Tecumseh" ; $\diamond-3005-03$ "Chrysler Airtemp"; 口 - CA5A

"Mitsubishi" (Japan); ○-500 FH "Hitachi" (Japan)

\section{DISCUSSING THE RESULTS}

A comparative analysis of the characteristics shows that HCU type HGV correspond to the level of the best samples of domestic and foreign technology. The range of nominal refrigerating capacities of HGV compressor units is much wider than existing domestic models.

Further improvement and increase in the energy performance of $\mathrm{HGV}$ compressors is possible by reducing the resistance of the suction path (increasing the flow cross sections for gas in the electric motor), as well as regulating the performance by changing the shaft rotation speed by adjusting the frequency of the supply network.

On the basis of the HGV-14 compressor unit with a 50 $\mathrm{Hz}$ mains power supply, a unified high-speed HCU type HGV-14-V was created with a $400 \mathrm{~Hz}$ power supply. It has higher energy performance (5-7\%) and a lower level of vibration $(15 \mathrm{~dB})$ compared to a previously produced similar compressor KHGV-14 [13].

In connection with the creation of domestic SCRM for ship provisioning pantries, the need for $\mathrm{HCU}$ for 


\section{ЕНЕРГЕТИЧНЕ МАШИНОБУДУВАННЯ № 1-2020}

work in the low-temperature area has increased. As a result of investigations of $\mathrm{HCU}$ of the HGV type in low-temperature regimes, a number of low-temperature compressor units were created and improved on their basis.: HGN-0.7 (HGV-4.5), HGN-1.4 (HGV-9.0), HGN3.5 (HGV-14.0), HGN-7.0 (HGV-28.0) [14].

\section{CONCLUSIONS}

Piston HCU continue to be in steady demand due to the proven production technology, high reliability and relatively low cost. They still have significant development potential that will allow them to be optimally used in shipboard EACR in the future.

In terms of mass, smoothness and compactness, modern piston $\mathrm{HCU}$ are quite competitive with rotary machines, and their characteristics such as ease of manufacture, low cost of maintenance, and maintainability make them attractive to many consumers and, above all, to the shipbuilding industry.

Adaptation of piston HCU to new applications and modern refrigerants is possible at relatively low costs. They are not so "finicky" to the purity of lubricants and do not require increased "sterility" during assembly, installation and repair. In addition, the restoration of worn surfaces does not require the use of highly sophisticated equipment and is quite feasible even in ship workshops.

Performance regulation by changing the speed, which is not yet generally accepted for piston $\mathrm{HCU}$, when used extensively, will result in significant energy savings.

Spiral HCU have certain advantages. However, the complexity of the technology of manufacturing spiral machines, the large initial costs of their production, the stringent requirements for the accuracy of manufacturing the entire structure do not allow to reduce the cost and impede the development of their production by a wide range of enterprises. The development and production of these compressors can only afford the largest world companies.

Therefore, based on our capabilities, as well as taking into account foreign experience, we should continue to develop high-tech production in our factories, create and improve piston HCU. Domestic reciprocating $\mathrm{HCU}$ type HGV and HGN correspond to the level of the best samples of domestic and foreign equipment, have significant development potential, which will allow them to be successfully used in shipboard air conditioning and refrigeration equipment in the future.

\section{REFERENCES}

[1] Martynovskiy, V. S., Brodyanskogo, V. M. (1979). Tsikly, skhemy i kharakteristiki termotransformatorov [Cycles, charts and descriptions of thermotransformers]. Moskva: Energiya. 288 p.

[2] Yakobson, V. B. (1977). Malyye kholodil'nyye mashiny [Small refrigeration machines]. Moskva: Food Industry. 368 p.

[3] Burenin, V. V. (2006). Vintovye kompressory dlya holodilnyh ustanovok [Screw compressors for refrigeration units]. Holodilnaya tehnika. No. 1. S. 40-43.

[4] Prashant Nema, Jitendra Raghuwanshi (2017). Analysis of VCRS by replacement of reciprocating compressor with screw compressor. International Journal of LNCT. Vol 2(7). P. 179-189.

[5] Gladchenko, A. (2005). Mirovoj lider po proizvodstvu kompressorov [World leader in compressor manufacturing]/ A. Gladchenko, S. Gorohov, S. Hodzhemirov. Holodilnaya tehnika. No. 2. S.18-21.

[6] Dorosh, V. S. (2008). Tendencii v razvitii holodilnyh germetichnyh kompressorov sudovyh sistem kondicionirovaniya $i$ refrizheracii [Trends in the development of refrigerated hermetic compressors of marine air conditioning and refrigeration systems]. Materiali I Mizhnar. n.-t. konf. "Holod v energetici i na transporti”, ch. II. Mikolayiv: NUK. S. 132-144.

[7] Zaharov, Yu. V. (1994). Sudovye ustanovki kondicionirovaniya vozduha i holodilnye mashiny [Marine air conditioning units and chillers] Sankt-Peterburg: Sudostroenie, 504 s.n

[8] Yefektivne spivrobitnictvo [Effective cooperation]. Holod. 2007. No. 3. S. 36-37.

[9] Standart 13 SEER - kakoj kompressor luchshe? [Standard 13 SEER - which compressor is better?]. Holodilnyj biznes. 2008. No. 4. S. 22-24.

[10] Standart 13 SEER - kakoj kompressor luchshe? [Standard 13 SEER - which compressor is better?]. Holodilnyj biznes. 2008. No. 5. S. 28-30.

[11] Dorosh, V. S. (1975). Vysokooborotnyj germetichnyj kompressor dlya sudovyh avtonomnyh kondicionerov [High-speed hermetic compressor for marine autonomous air conditioners] / V. S. Dorosh, Yu.K. Kolomiec, B.D. Redkozub. Holodilnaya tehnika. No 2. S. 8-10.

[12] Novyj ryad vysokooborotnyh germetichnyh holodilnyh kompressorov dlya sudovyh avtonomnyh kondicionerov [A new range of high-speed hermetic refrigeration compressors for marine autonomous air conditioners] / V. S. Dornosh, V. I. Gidulyan, V. Yu. Zaharov, Yu. K. Kolomiec. Holodilnaya tehnika. 1983. No 5. S. 19-23.

[13] Dorosh, V. S. (2002). Sozdanie i sovershenstvovanie unificirovannogo vysokooborotnogo germetichnogo kompressora dlya avtonomnyh kondicionerov amfibijnyh sudov [Creation and improvement of a unified high-speed hermetic compressor for autonomous air conditioners of amphibious vessels]. Zb. nauk. pr. UDMTU. Mikolayiv: UDMTU, No. 1 (379). S. 75-82.

[14] Dorosh, V. S. (2005). Germetichnye holodilnye mashiny dlya provizionnyh kladovyh [Hermetic refrigeration machines for food pantrys] / V. S. Dorosh, I. A. Nazarenko, E. V. Lytosh. Holodilnaya tehnika i tehnologiya. Odessa: OGAH, No. 4 (96). S.62 -64. 


\section{BIBLIOGRAPHY}

[1] Мартыновский, В. С. (1979). Циклы, схемы и характеристики термотрансформаторов. / под ред. В. М. Бродянского. Москва : Энергия.

[2] Якобсон, В. Б. (Ред.). (1977.) Малые холодильные машины. Москва : Пищевая промышленность.

[3] Буренин, В. В. (2006). Винтовые компрессоры для холодильных установок. Холодильная техника, № 1, с. 40-43.

[4] Prashant Nema, Jitendra Raghuwanshi. (2017). Analysis of VCRS by replacement of reciprocating compressor with screw compressor. International Journal of LNCT, Vol 2(7), p. 179-189.

[5] Гладченко, А., Горохов, С., Ходжемиров, С. (2005). Мировой лидер по производству компрессоров. Холодильная техника, № 2, с. 18-21.

[6] Дорош, В. С. (2008). Тенденции в развитии холодильных герметичных компрессоров судовых систем кондиционирования и рефрижерации. Холод в енергетиці і на транспорті: Матеріали І міжнародної науково-технічної конференції, ч. ІІ. Миколаїв : НУК, С. 132-144.

[7] Захаров, Ю. В. (1994). Судовые установки кондиционирования воздуха и холодильные машины. Санкт-Петербург : Судостроение.

[8] Ефективне співробітництво. (2007). Холод, № 3, с. 36-37.

[9] Стандарт 13 SEER - какой компрессор лучше? (2008). Холодильный бизнес. № 4, с. 22-24.

[10] Стандарт 13 SEER - какой компрессор лучше? (2008). Холодильный бизнес. № 5, с. 28-30.

[11] Дорош, В. С., Коломиец, Ю. К., Редкозуб, Б. Д. (1975). Высокооборотный герметичный компрессор для судовых автономных кондиционеров. Холодильная техника, № 2, с. 8 -10.

[12] Дорош, В. С. , Гидулян, В. И., Захаров, В. Ю., Коломиец, Ю. К. (1983). Новый ряд высокооборотных герметичных холодильных компрессоров для судовых автономных кондиционеров. Холодильная техника, № 5, с. 19-23.

[13] Дорош, В. С. (2002). Создание и совершенствование унифицированного высокооборотного герметичного компрессора для автономных кондиционеров амфибийных судов. Зб. наук. пр. УДМТУ. Миколаїв : УДМТУ. № 1 (379), c. $75-82$.

[14] Дорош, В. С., Назаренко, И. А., Лытош, Е. В. (2005). Герметичные холодильные машины для провизионных кладовых. Холодильная техника и технология. Одесса : ОГАХ. № 4 (96). С. $62-64$.

(C) O. V. Lytosh, Ji Ran

Дата надходження статті до редакції: 07.04.2020 Дата затвердження статті до друку: 17.04.2020 